\title{
Relationship between Apolipoprotein(a) Phenotype, Lipoprotein(a) Concentration in Plasma, and Low Density Lipoprotein Receptor Function in a Large Kindred with Familial Hypercholesterolemia due to the pro $_{664} \rightarrow$ leu Mutation in the LDL Receptor Gene
}

\author{
A. K. Soutar, S. N. McCarthy, M. Seed, and B. L. Knight \\ Medical Research Council Lipoprotein Team, Hammersmith Hospital, London W12 OHS, UK
}

\begin{abstract}
In a large kindred of 66 individuals, 22 were identified as heterozygous and 3 as homozygous for a mutation (pro $664 \rightarrow$ leu) in the LDL-receptor gene that gives rise to familial hypercholesterolaemia (FH). All the heterozygotes had a raised level of plasma total cholesterol and low density lipoprotein cholesterol, but were remarkably free from premature coronary disease. Determination of apolipoprotein(a) (apo(a)) phenotype and lipoprotein(a) $(\mathrm{Lp}(\mathrm{a}))$ concentration in plasma revealed that in many instances, involving individuals with various apo(a) phenotypes, there was no difference in plasma $L p(a)$ concentration between an FH heterozygote and an unaffected sibling with the same apo(a) phenotype. No significant difference in $L p(a)$ concentration was observed between groups of FH and non-FH of the same apo(a) phenotype, although in each case the mean value for the FH group was greater than that for the non-FH group. There was also evidence for an inherited trait that markedly increased $L p(a)$ concentration, which did not segregate with apo(a) phenotype or the defective LDL-receptor allele. The data provide no evidence for a strong multiplicative interaction between the gene loci for apo(a) and the LDL receptor. (J. Clin. Invest. 1991. 88:483-492.) Key words: gene amplification • coronary heart disease $\bullet$ immunoblotting $\bullet$ high density lipoprotein $\bullet$ immunoassay
\end{abstract}

\section{Introduction}

Familial hypercholesterolaemia $(\mathrm{FH})^{1}$ is an inherited disorder in which a mutation in the gene for the LDL receptor results in defective catabolism of plasma LDL (1). Approximately 1 in 400 persons in most populations carries one defective gene for the LDL receptor, but homozygotes, who are much more se-

Address correspondence and reprint requests to Dr. Anne K. Soutar, MRC Lipoprotein Team, Hammersmith Hospital, Ducane Road, London W12 OHS, U.K.

S. McCarthy's present address is University College London, The Rayne Institute, Faculty of Clinical Sciences, University Street, London WC1E 6JJ, U.K. Dr. Seed is presently at the Department of Medicine, Charing Cross and Westminster Medical School, London, U.K. 1991.

Received for publication 26 July 1990 and in revised form 1 March

1. Abbreviations used in this paper: $\mathrm{CHD}$, coronary heart disease; $\mathrm{FH}$, familial hypercholesterolemia; HMG CoA, 3-hydroxy-3-methylglutaryl Coenzyme A; Lp(a), lipoprotein(a).

J. Clin. Invest.

(c) The American Society for Clinical Investigation, Inc. 0021-9738/91/08/0483/10 \$2.00

Volume 88, August 1991, 483-492 verely affected, are rare. The disorder is characterized by a marked increase in the plasma concentration of LDL and the presence of tendon xanthomata, and is often associated with a family history of premature coronary heart disease (CHD) (2).

It has long been recognized that there is considerable variation in the severity of the symptoms amongst FH heterozygotes, but the molecular basis of this is not fully understood. One explanation undoubtedly lies in the diversity of defects in the LDL receptor gene, in that more than 20 different mutations have already been described while many more remain to be identified (3).

Although LDL receptor gene defects can be broadly classified as "receptor-negative" or "receptor-defective" according to their effect on the function of LDL receptors in cultured skin fibroblasts from FH patients (1), there is not always a strong correlation between residual receptor activity and the severity of the disease in the patient (Soutar, A. K., G. R. Thompson, and B. L. Knight, unpublished observations). It is not altogether surprising that other factors may be involved, because numerous genetic and environmental risk factors for CHD have been identified in the general population (4). For example, a high concentration of lipoprotein(a) $(\mathrm{Lp}(\mathrm{a}))$ in plasma is associated with a considerable risk for development of premature CHD (5), and it has recently been suggested that some, if not all, of the severity of CHD amongst FH heterozygotes depends on the plasma concentration of $\operatorname{Lp}(\mathrm{a})(6)$. $\mathrm{Lp}$ (a) comprises an LDL-like lipoprotein particle to which another glycoprotein, apolipoprotein (apo)(a), is tightly associated (7). There is considerable inherited phenotypic variation in the apparent size of apo(a) between individuals $(8,9)$ and it has been found that, in a Tyrolean population, there is a strong association between apo(a) phenotype and the concentration of $\operatorname{Lp}(a)$ in plasma (9). However, the mechanisms regulating Lp(a) metabolism are poorly understood and it has not yet been fully established what role the LDL receptor plays $(10,11)$. Data from a heterogeneous group of clinically diagnosed $\mathrm{FH}$ heterozygotes attending lipid clinics has shown that, within each apo(a) phenotype, the $\mathrm{Lp}(\mathrm{a})$ concentration in the plasma of FH heterozygotes is, on average, threefold higher than normal (12). This observation has led Utermann and colleagues to suggest that premature CHD in FH does not result from a single gene defect in the LDL receptor gene, but requires the interaction of at least two genes $(6,12)$.

We have recently identified a mutation in the LDL receptor gene of an FH homozygote of Asian-Indian origin, in which substitution of a proline residue at amino acid residue 664 with leucine (13) results in a receptor-defective phenotype. The precursor form of the mutant receptor is converted more slowly than normal and the mature form on the cell surface binds LDL less well than normal (14). 
The proband is a member of a large family in which there are several first cousin marriages in each generation that has resulted in four homozygotes and numerous heterozygotes in the kindred. We now report our findings on the effect of this mutation in the LDL receptor gene on the concentration of plasma lipids and lipoproteins; in particular, we have focussed on the possible relationship between LDL receptor function, apo(a) phenotype and the concentration of $\mathrm{Lp}(\mathrm{a})$ in plasma.

\section{Methods}

Subjects. Blood samples were obtained from 66 members of the family now resident in the UK or visiting from Zambia. The family is Muslim and originates from Gujerat in the west coast area of India, they had maintained their traditional, nonvegetarian diet, and none were smokers. Each member of the family was assigned a number. A history for symptoms of CHD and drug treatment was obtained, and the presence of tendon xanthomata was noted. There was no opportunity for investigation of CHD in asymptomatic subjects. Only numbers 1 and 23 had symptomatic $\mathrm{CHD}$; both were being treated with an inhibitor of 3-hydroxy-3-methylglutaryl Coenzyme A (HMG-CoA) reductase, a $\beta$ blocker and a vasodilator; number 27 was also treated with an inhibitor of HMG-CoA reductase. Two of the three homozygous FH subjects were treated with two-weekly plasma exchange (numbers 16 and 42); number 42 was also treated with probucol. The third homozygote (number 56) had been off treatment for 1 mo due to a suspected gastric ulcer, but had been treated with weekly plasma exchange and an HMG-CoA reductase inhibitor.

Venous blood was collected into tubes containing EDTA and immediately chilled. Plasma was separated by centrifugation within $2 \mathrm{~h}$, and a sample immediately frozen on dry ice for determination of the apo(a) phenotype, $\mathrm{Lp}(\mathrm{a})$, apo AI, and apo B concentration. The remainder of the plasma was maintained at $4^{\circ} \mathrm{C}$ for determination of total plasma cholesterol, LDL and HDL cholesterol, and apo E phenotype. The cells were frozen on dry ice for subsequent isolation of DNA.

Detection of the pro $_{664} \rightarrow$ leu mutation in the LDL receptor gene. Genomic DNA was isolated from frozen blood cells essentially as described by Grimberg et al. (15), except that digestion with proteinase $\mathrm{K}$ was at $37^{\circ} \mathrm{C}$ in a shaking incubator for $12-16 \mathrm{~h}$. A tenfold dilution in water of the DNA solution so obtained was heated at $94^{\circ} \mathrm{C}$ for $20 \mathrm{~min}$ to denature the proteinase $\mathrm{K}$. A fragment of $492 \mathrm{bp}$ encompassing exons 13 and 14 of the LDL receptor gene was amplified and digested with PstI essentially as described previously for genomic DNA (13), with the exception that the oligonucleotide primers were present in the amplification reaction at a concentration of $2.0 \mu \mathrm{g} / \mathrm{ml}$ and were as follows:

5'-aatgtcgac GTC ATC TTC CTT CCT TGC TGC CTG T-3'; 5'-tatgtcga CAG AAA CAA GGC GTG TGC CAC-3'.

The lower case letters denote non-LDL receptor-specific sequences that were included to provide recognition sites for the restriction enzyme Sall. The concentration of genomic DNA ( $10 \mu$ l of the tenfold dilution per $100 \mu$ lincubation mix) in the amplification reaction was $2-5 \mu \mathrm{g} / \mathrm{ml}$.

Determination of plasma lipids and lipoproteins. The sample of plasma frozen at the time blood was collected was thawed, divided into small portions $(\sim 20 \mu \mathrm{l})$, and stored frozen at $-70^{\circ} \mathrm{C}$ until required. Thus, determinations of $\mathrm{Lp}(\mathrm{a})$, apo $\mathrm{B}$, and apo $\mathrm{AI}$ concentrations or apo(a) phenotype were always performed on samples that had been frozen and thawed twice. There was no apparent difference between values obtained with fresh samples and with samples treated in this way.

Lp(a) concentration was assayed with a "Tint Elize Lp(a)" enzyme immunoassay kit (Biopool AB, Umeå, Sweden) using the dilutions and procedures recommended by the manufacturer. The assay gave no signal with plasminogen at a concentration less than $1 \mathrm{mg} / \mathrm{ml}$ in the undiluted plasma. Samples that gave values close to or above that of the highest standard were reassayed with one-half of the normal volume of diluted sample in the reaction well. 10 samples assayed in this way gave plasma values that were the same $(101.5 \pm 1.9 \%$, mean $\pm \mathrm{SE})$ as those obtained by the standard procedure.

The plasma apo B and apo AI concentrations were determined with commercially available kits, using the procedure recommended by the manufacturer (Boehringer Mannheim CBR-program; Mannheim, FRG).

Plasma lipid determinations were made within 1 wk of blood collection. Plasma that had been stored at $4^{\circ} \mathrm{C}(5 \mathrm{ml})$ was centrifuged at $d$ $1.006 \mathrm{~g} / \mathrm{ml}$ for $16 \mathrm{~h}$ at $8^{\circ} \mathrm{C}$ in a 50.3 rotor (Beckman Instrs., Inc., Fullerton, CA), and the VLDL fraction obtained by tube slicing. VLDL was stored frozen at $-20^{\circ} \mathrm{C}$ for subsequent determination of apo $\mathrm{E}$ phenotype.

Plasma HDL cholesterol was determined by assaying the concentration of cholesterol in the supernatant obtained after heparin-manganese precipitation (16) of the $d>1.006 \mathrm{~g} / \mathrm{ml}$ fraction of plasma, while LDL cholesterol was determined as the difference between the cholesterol concentration in the $d>1.006 \mathrm{~g} / \mathrm{ml}$ fraction and HDL cholesterol.

Because it was not possible to obtain fasting samples from all members of the family, fasting plasma triglyceride levels could not be determined.

Determination of apo(a) and apo E phenotypes. Apo(a) phenotype was determined by procedures based on those described by Kraft et al. (17). Samples of frozen plasma $(25 \mu \mathrm{l})$ were lyophilized and delipidated overnight with acetone-ethanol $(1: 1, \mathrm{vol} / \mathrm{vol})$. The precipitates were washed once with diethyl ether, dried, and dissolved by boiling for 10 min with $50 \mu \mathrm{l}$ of sample buffer ( $2 \mathrm{ml}$ of $5 \%$ SDS with $200 \mu \mathrm{l}$ of $\beta$-mercaptoethanol and $300 \mu \mathrm{l}$ of bromophenol blue in glycerol). Samples were centrifuged for 5 min in a Beckman microfuge and portions of the supernatant were subjected to discontinuous SDS-PAGE at room temperature according to the method of Laemmli (18), using $20 \mathrm{~cm} \times 20$ $\mathrm{cm}$ vertical, $1 \mathrm{~mm}$ thick gels with a $3 \%$ polyacrylamide running gel and a $2.5 \%$ polyacrylamide stacking gel. The volume of supernatant applied was broadly related to the concentration of $\operatorname{Lp}(a)$ in the original plasma, with $20 \mu \mathrm{l}$ added for concentrations up to $10 \mathrm{mg} / \mathrm{dl}, 15 \mu \mathrm{l}$ for concentrations of $10-20 \mathrm{mg} / \mathrm{dl}, 10 \mu \mathrm{l}$ for concentrations of $20-40 \mathrm{mg} /$ $\mathrm{dl}$, and $5 \mu \mathrm{l}$ for higher concentrations. To detect faint minor bands, phenotyping was repeated with $30 \mu$ l of lyophilized and delipidated supernatant. Larger sample volumes resulted in a distorted pattern and reduced sensitivity. Samples were run through the stacking gel at $150 \mathrm{~V}$ and then through the running gel at $200 \mathrm{~V}$ for $1 \mathrm{~h}$ after the dye front had reached the end of the gel. Proteins were transferred to nitrocellulose membranes as described by Beisiegel et al. (19) and the membranes were blocked by incubation for $30 \mathrm{~min}$ at $37^{\circ} \mathrm{C}$ in $25 \mathrm{ml}$ of $10 \mathrm{mM}$ Tris- $\mathrm{HCl}$ buffer, $\mathrm{pH} 7.4$, containing $150 \mathrm{mM} \mathrm{NaCl}, 0.2 \%$ Nonidet $\mathrm{P} 40$, and $50 \mathrm{mg} / \mathrm{ml}$ bovine serum albumin. Membranes were then incubated on a rocking platform for $2 \mathrm{~h}$ at room temperature with $20 \mathrm{ml}$ of blocking buffer containing $1 / 400$ dilution of sheep anti-Lp(a) antibody (6.0 mg antibody/ml; Immuno, Vienna) and washed in $10 \mathrm{mM}$ Tris$\mathrm{HCl}$ buffer, $\mathrm{pH} 7.4$, containing $150 \mathrm{mM} \mathrm{NaCl}, 0.1 \%$ SDS, $0.25 \%$ sodium deoxycholate, and $0.2 \%$ Nonidet $\mathrm{P} 40$. The antibody preparation did not detect apo B. Bound antibody was detected by incubation for 1 $h$ at room temperature with $1 / 200$ dilution of peroxidase-linked antigoat IgG antiserum (610 U/ml; ICN Immunobiologicals, Lisle, France) in blocking buffer, followed by washing as above and development in substrate solution $(0.4 \mathrm{mg}$ 4-chloro-1-naphthol/ $\mathrm{ml}$ in $10 \mathrm{mM}$ Tris $\mathrm{HCl}$, pH 7.4, containing $150 \mathrm{mM} \mathrm{NaCl}$ and $0.03 \% \mathrm{H}_{2} \mathrm{O}_{2}$ ). The distances travelled in the running gel by the bands of apo(a) were expressed as a ratio to that travelled by apo $B$, determined by comparison with standard apo(a) samples whose mobility had previously been characterized on $5 \%$ polyacrylamide gels. The reproducibility of these values was checked by running a variety of samples on six separate gels. The distances travelled relative to apo $B( \pm S D)$ were $0.442 \pm 0.010$ (range 0.43 0.46 ), $0.501 \pm 0.020$ (range $0.48-0.53$ ), $0.605 \pm 0.005$ (range $0.60-0.61$ ), $0.716 \pm 0.082$ (range $0.71-0.73$ ), and $0.856 \pm 0.028$ (range $0.82-0.88$ ).

Apo E phenotype was determined as described by Warnick et al. (20). 

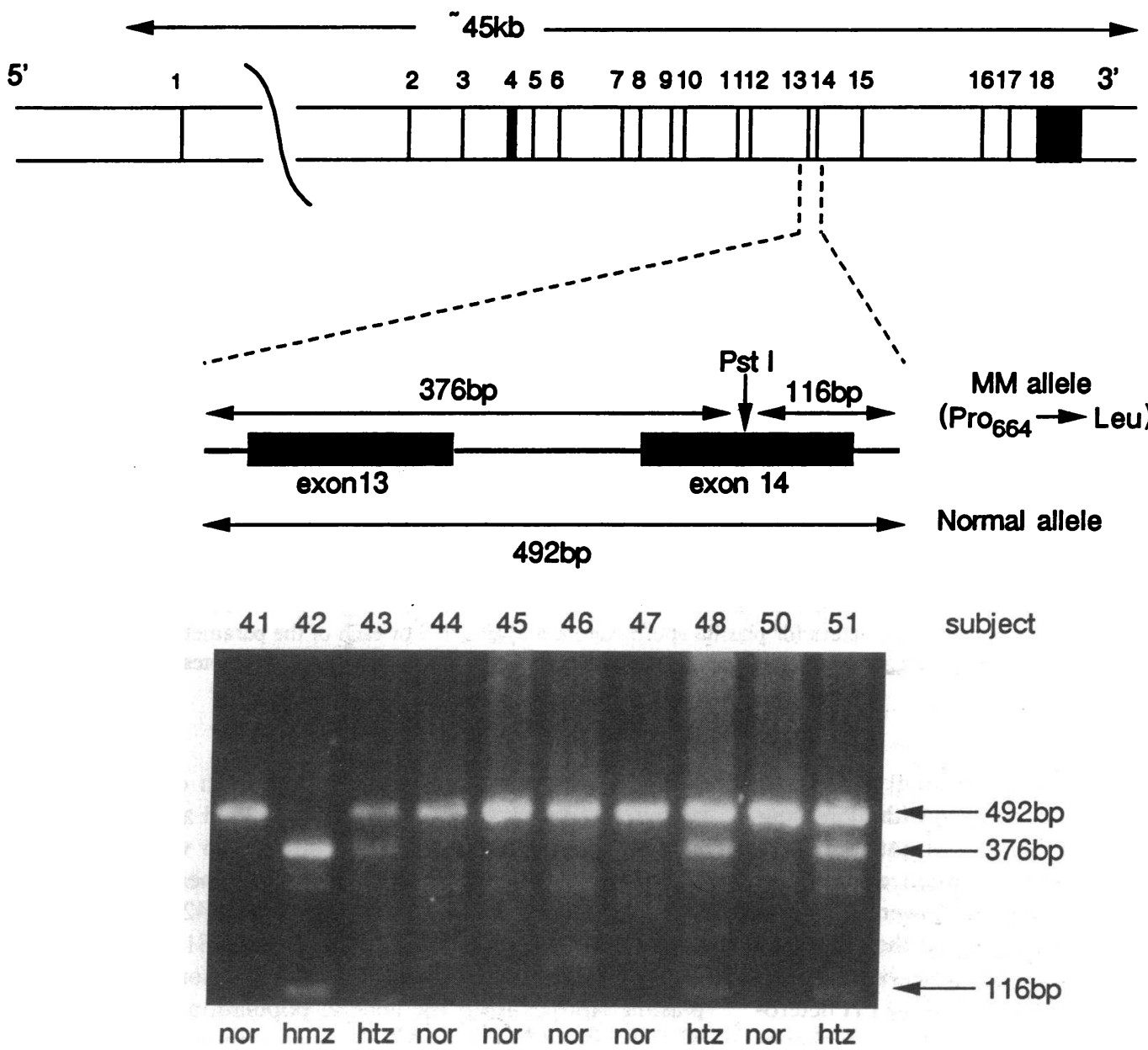

Figure 1. Detection of the pro $_{664} \rightarrow$ leu mutation in the LDL receptor gene. A fragment of the LDL receptor gene (492 bp) encompassing exons 13 and 14 was amplified from genomic DNA and digested with PstI. The amplified, digested fragments were separated by electrophoresis on a $2 \%$ (wt/vol) agarose gel and stained with ethidium bromide. $h m z$, Homozygote; $h t z$, heterozygote; nor, normal.

\section{Results}

Genomic DNA from each member of the family was analyzed for the presence of the pro $_{664} \rightarrow$ leu mutation in the LDL receptor gene by amplification and restriction enzyme digestion of a fragment comprising exons 13 and 14 together with short flanking sequences from introns on either side. The $\mathrm{C} \rightarrow \mathrm{T}$ mutation introduces a PstI site in exon 14, so that the mutant 492-bp fragment is digested by this enzyme to give bands of 116 and $376 \mathrm{bp}$ (Fig. 1). Subjects in whom only the digested bands were observed were identified as homozygous for the mutant allele, while subjects in whom half the original 492-bp fragment remained after digestion were identified as heterozygotes. The LDL receptor genotypes of the subjects from whom a blood sample was analyzed are shown in the pedigree of this kindred in Fig. 2. Out of 65 blood relatives of the original proband M.M. (No. 56 in the pedigree) and their spouses, 2 further homozygotes and 22 heterozygotes were identified. Also designated on the pedigree are obligate heterozygotes from whom samples were unobtainable, and a deceased homozygote sibling of No. 56, previously identified on the basis of clinical diagnosis.

The details of the lipid and lipoprotein analyses, together with relevant clinical information, are provided in Appendix 1. In all the members of the family who were heterozygous for the pro $_{664} \rightarrow$ leu mutation in the LDL receptor gene, the concentrations of total plasma cholesterol, LDL cholesterol, and plasma apo B were significantly higher than in the non-FH

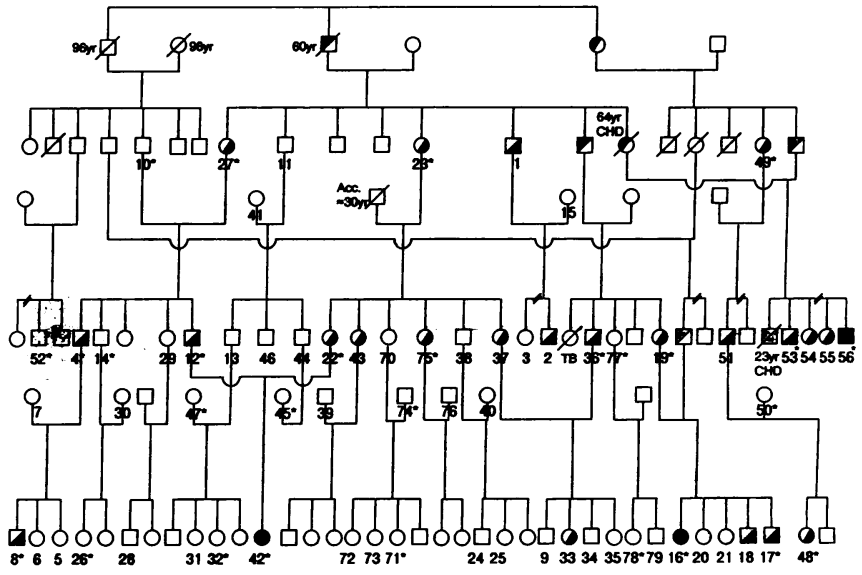

Figure 2. Pedigree of the relatives of MM. Subjects ( $\square$, male; $\circ$, female) from whom a blood sample was obtained were assigned a number; those without a number were not available for study. Individuals who are heterozygous $(\square, 0)$ and homozygous $(n, \bullet)$ for the pro $_{664} \rightarrow$ leu mutation in the LDL receptor gene are shown; obligate FH heterozygotes $(\square)$ are also shown, as is one deceased homozygote (a) identified previously on the basis of clinical diagnosis. Those individuals known to be no longer alive are denoted by a diagonal line; the cause of death, where known, is stated ( $A C C$, accidental death; $C H D$, coronary heart disease; TB, tuberculosis). Broken lines indicate where siblings not available for study have been omitted for clarity. Individuals marked with an asterisk (*) have an Lp(a) concentration in plasma that is greater than the expected value for their apo(a) phenotype (see text for details). 

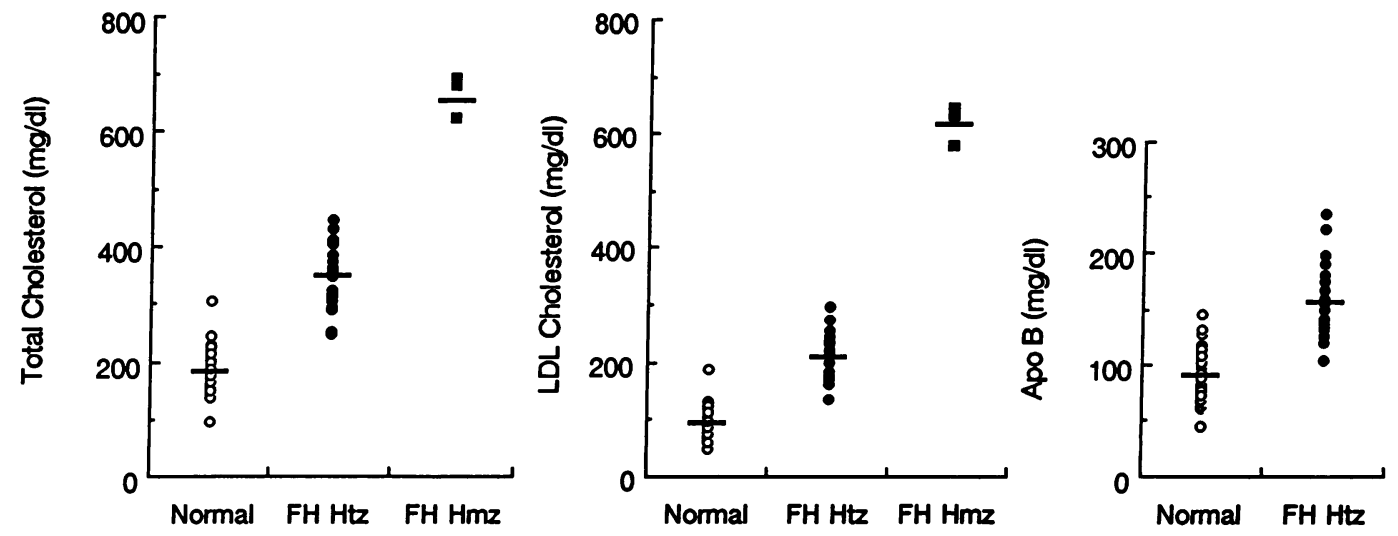

Figure 3. Total plasma cholesterol, plasma apo $B$, and LDL cholesterol concentrations in the normal and FH members of the kindred. For the 40 normal subjects, the mean value \pm the standard deviation for plasma total cholesterol was $189.6 \pm 35.8 \mathrm{mg} / \mathrm{dl}$, for LDL cholesterol was $93.1 \pm 26.2 \mathrm{mg} / \mathrm{dl}$, and for plasma apo B was $89.8 \pm 21.3 \mathrm{mg} / \mathrm{dl}$. The values include data from one subject (7 in Fig. 2)

in the third trimester of pregnancy. For the $22 \mathrm{FH}$ heterozygotes $(\mathrm{Htz})$ with the pro $\mathrm{O}_{64} \rightarrow$ leu mutation, the mean value for total plasma cholesterol was $343.3 \pm 55.1 \mathrm{mg} / \mathrm{dl}$, for LDL cholesterol was $208.5 \pm 39.5 \mathrm{mg} / \mathrm{dl}$, and for plasma apo B was $155 \pm 33.0 \mathrm{mg} / \mathrm{dl}$. The values for the heterozygotes include data from three individuals who were receiving lipid-lowering therapy (see Methods for details). The mean value for total plasma cholesterol for the three homozygotes $(\mathrm{Hmz})$ was $655 \pm 36.2 \mathrm{mg} / \mathrm{dl}$, and for LDL cholesterol was $618 \pm 35.8 \mathrm{mg} / \mathrm{dl}$. The values for the homozygotes were those made at the time of referral, before treatment; values for plasma apo B were not available. For each of the parameters, there was a significant difference in the mean values between normal and FH heterozygotes and between heterozygotes and homozygotes (Student's $t$ test, $P<0.001)$.

members of the family (Fig. 3). There was a small but significant increase in LDL cholesterol concentration with increasing age in the non-FH members of the family, but not in the FH heterozygotes (Fig. 4). The mean value for the concentration of HDL cholesterol and apo AI in plasma was lower in the FH heterozygotes than in the non-FH subjects, but the difference in mean HDL cholesterol concentration observed between non-FH males and females was not observed in the FH heterozygotes (Fig. 5). The majority of the subjects were apo E phenotype E3/E3, although 11 subjects were apo E3/E4 and 1 was apo E2/E3 (see Appendix 1).

The apo(a) phenotype of each subject was determined by identification of bands, separated by SDS-gel electrophoresis of plasma, by immunoblotting with a specific antibody to $\mathrm{Lp}(\mathrm{a})$. Two clearly separate apo(a) bands were detected in samples from 52 of the 66 subjects, while only one band could be detected in the remaining 14 samples even when gels were loaded with as much $\operatorname{Lp}(a)$ as was consistent with maintaining sufficient resolution. From the pedigree, 10 of these could be deduced to be heterozygous for an apparently null allele, while the remaining 4 subjects could have been either homozygous for the single band or heterozygous for a null allele. As shown in Fig. 6, the mobility of the apo(a) bands relative to that of apo

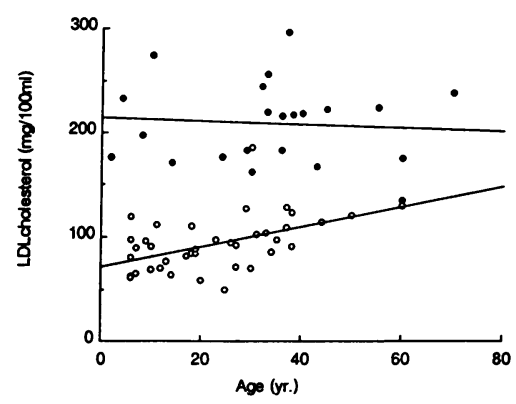

Figure 4. Effect of age on plasma LDL cholesterol in normal and $\mathrm{FH}$ members of the kindred. There was a small but significant effect of increasing age on the concentration of LDL cholesterol in plasma in the normal subjects $(r=0.304, n$ $=39$ ), but not for the

FH heterozygotes $(r=0.005, n=22)$. The LDL cholesterol value for subject 7 (non-FH) who was in the third trimester of pregnancy, was omitted for determination of the correlation coefficient.
B fell into nine clearly defined groups each of which represented an apo(a) phenotypic band identified according to the median mobility of the group. Comparison with samples in which apo(a) phenotype had been determined by Utermann and colleagues (12) showed that phenotypes 42-51 correspond to $S 4,61-65$ to $S 3,71$ to $S 2$, and 92 to $S 1$. We have also identified nine other phenotypes ranging from 39 to 114 in plasma samples from the general population (Knight, B. L., Y. F. N. Perombelon, and A. K. Soutar, unpublished observations). In this kindred, apo(a) phenotype was apparently inherited according to a Mendelian mode of inheritance.

The concentration of $L p(a)$ in the plasma of the non-FH heterozygotes and FH homozygotes of each apo(a) phenotype is shown in Fig. 7. The subjects are grouped according to the phenotypic apo(a) band of highest mobility which, in the majority of cases, made the dominant contribution to plasma apo(a). The highest $L p(a)$ concentrations were seen in subjects with a phenotypic apo(a) band 92. Otherwise, there was no obvious association between $\mathrm{Lp}(\mathrm{a})$ concentration and apo(a) phenotype. This was most clearly demonstrated in subjects in whom there was an apparently null allele, where a single apo(a) phenotypic band determined the plasma concentration. The majority of the FH subjects were apo(a) phenotype 61 in combination with another slower migrating band, and it was only within this group that it was possible to make statistical comparisons between FH and normal subjects. As shown in Table I, although the mean value for plasma $\mathrm{Lp}(\mathrm{a})$ concentration of $\mathrm{FH}$ heterozygotes was greater than that of non-FH subjects of each phenotype, there was no statistically significant difference, even when the data for all FH and non-FH subjects with a dominant phenotypic apo(a) band 61 were combined. In subjects with apo(a) phenotype 51/48, a homozygous FH subject had a concentration of $\mathrm{Lp}(\mathrm{a})$ almost twofold that of the heterozygote, but this difference was not observed with the other two homozygotes, with apo(a) phenotype $61 / 51$ and $92 / 42$. In the group with the dominant 92 apo(a) phenotypic band that was associated with a very high concentration of $L p(a)$ in plasma, there was no apparent difference between FH and non-FH subjects. 

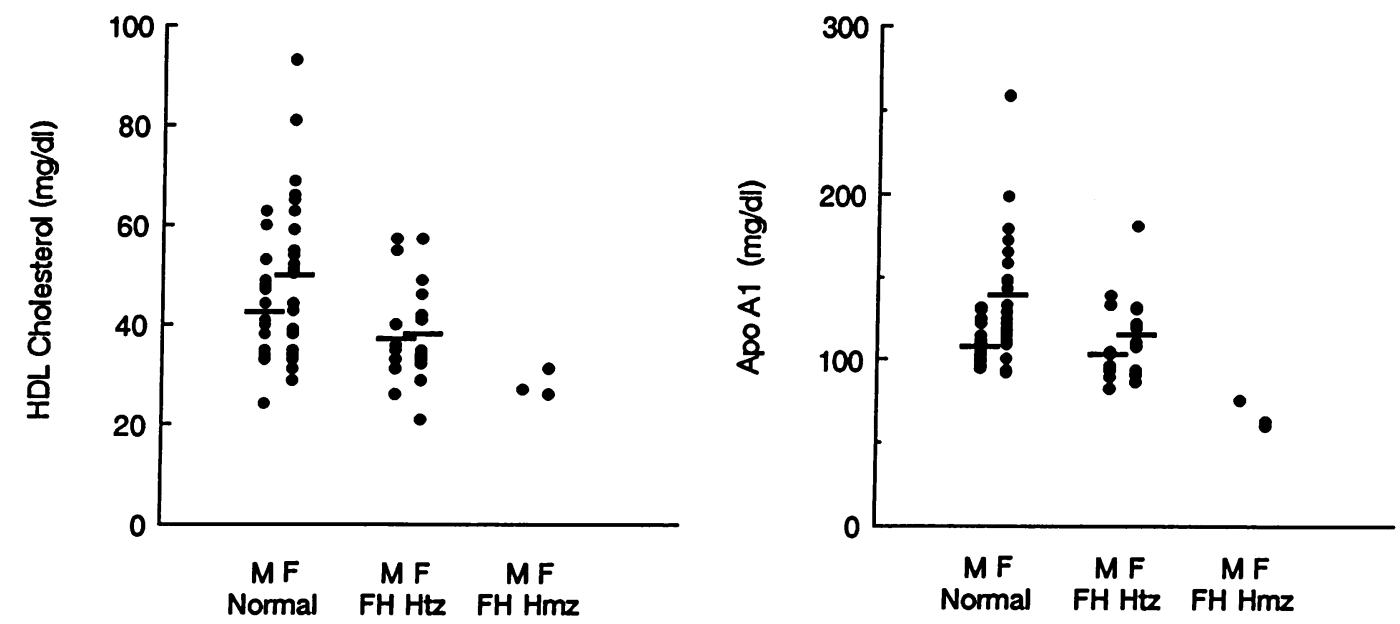

Figure 5. Plasma HDL cholesterol and apo AI concentrations in normal and heterozygous $(\mathrm{Htz})$ FH male and female subjects. The mean value \pm the standard deviation for plasma $\mathrm{HDL}$ cholesterol for 16 normal males was $42.6 \pm 10.4 \mathrm{mg} /$ $\mathrm{dl}$, for 25 normal females was $50.0 \pm 16.3 \mathrm{mg} / \mathrm{dl}$, for $10 \mathrm{FH}$ heterozygous males with the pro $_{664} \rightarrow$ leu mutation was $37.0 \pm 10.9 \mathrm{mg} / \mathrm{dl}$, and for 12 FH heterozygous females was $37.8 \pm 9.7 \mathrm{mg} /$ dl. For plasma apo AI concentration, the mean value \pm the standard deviation for normal males was $109.9 \pm 11.9 \mathrm{mg} / \mathrm{d}$, for normal females was $135.6 \pm 37.0 \mathrm{mg} / \mathrm{dl}$, for FH heterozygous males was $102.2 \pm 18.6 \mathrm{mg} / \mathrm{dl}$, and for heterozygous females was $118.25 \pm 25.0 \mathrm{mg} / \mathrm{dl}$. The only difference observed at a significant level was between the apo AI concentration in normal males and normal females (Student's $t$ test, $P<0.05$ ). Hmz, homozygous.

Within the groups shown in Table $I$ in. which sufficient subjects were available to make a comparison, there was no apparent effect of increasing age on the plasma concentration of $\mathrm{Lp}(\mathrm{a})$, nor was there a significant difference between males and females.

The lack of a direct effect of the LDL receptor defect on the plasma concentration of $\mathrm{Lp}(\mathrm{a})$ is clearly demonstrated by comparing siblings or parents and children in the branches of the family shown in Fig. 8. In family B, for example, siblings 43 , 70 , and 37 are all apo(a) phenotype 61/55, as are siblings 33 and 35 , and there is no increase in $\operatorname{Lp}(a)$ concentration in the FH heterozygotes compared with the non-FH individual. Similarly, in family $\mathrm{C}$ there is no effect of $\mathrm{FH}$ on $\mathrm{Lp}(\mathrm{a})$ concentration discernable in siblings 20,21 , and 18 with apo(a) phenotype 71/61, nor in siblings 77 and 19 with apo(a) phenotype 92/61, nor siblings 2 and 3 with apo(a) phenotype 92/N. In family $C$ it is also possible to compare the $L p(a)$ concentration in a homozygote with a heterozygote of the same apo(a) phenotype, in that siblings 16 and 17 are both apo(a) phenotype 92/ 42 and have virtually identical $L p(a)$ concentrations in plasma.

In contrast, in family $\mathrm{A}$ it is possible to discern an apparent association between the defective $L D L$ receptor gene and $L p(a)$ concentration in that homozygous FH 42 has an Lp(a) concentration almost twice that of her heterozygous $\mathrm{FH}$ father 12 with the same phenotype. However, an unaffected sibling of the FH heterozygote father with the same apo(a) phenotype does not have an $\mathrm{Lp}(\mathrm{a})$ concentration that is half that of his affected brother.

It is clear from the data shown in Fig. 7 and from the families shown in Fig. 8 that some subjects, both FH and non-FH, have an $\mathrm{Lp}(\mathrm{a})$ concentration in plasma that is markedly higher than that of most of the subjects with the same phenotype in this kindred. For example, subject 53 in family C, who is an FH heterozygote, has an $\mathrm{Lp}$ (a) concentration almost three times that of his two FH heterozygote siblings with the same apo(a) phenotype, and the concentration of $\mathrm{Lp}(\mathrm{a})$ in 77 with apo(a) phenotype $92 / 61$, is twice that in 15 with apo(a) phenotype $92 / 51$; in the second example, both subjects have the dominant 92 band in combination with a minor band. Because several of the close relatives of 77 also have anomalously high levels of $\mathrm{Lp}(\mathrm{a})$ in plasma, while those of 15 with the same apo(a) phenotype do not, the possibility exists that some inherited factor not linked to apo(a) phenotype or LDL receptor function influences plasma $\mathrm{Lp}(\mathrm{a})$ concentration.

In order to investigate this further, those members of the kindred in whom Lp(a) concentration was greater than the "expected" value for an individual with this apo(a) phenotype were identified. The "expected" value for an individual was calculated as twice the $\mathrm{Lp}(\mathrm{a})$ concentration of a subject with an apparently null allele in combination with the dominant phenotypic band in the individual in question. Thus, for example, the "expected" value for an individual with apo(a) phenotype 61 in combination with another band of lower mobility would be twice that of an individual with apo(a) phenotype $61 / \mathrm{N}$. All individuals with $\mathrm{Lp}(\mathrm{a})$ concentration greater than the expected value are marked with an asterisk $\left({ }^{*}\right)$ in the pedigree shown in Fig. 2. The effect was observed in both normal and heterozygous FH individuals, and was not limited to any particular phenotype. In total, 12 of 40 non-FH, 13 of 22 FH heterozygotes, and 3 of $3 \mathrm{FH}$ homozygotes were identified. In each case where a child had an anomalously high concentration of $\mathrm{Lp}(\mathrm{a})$ in plasma, the effect was seen in at least one parent, and where one or both parents had an anomalously high $\mathrm{Lp}(\mathrm{a})$ concentration, at least one of the children was also affected. Three families were identified in which neither parents nor children were affected. The effect was not restricted to blood relatives in that several of the spouses appeared to have anomalously high Lp(a) levels. These observations suggest, but do not confirm, that at least some of the apparent increase in $\mathrm{Lp}(\mathrm{a})$ concentration observed in a number of $\mathrm{FH}$ heterozygotes in this particular kindred may not be due to the defective LDL receptor gene but to some other inherited factor. It is of interest to note that both the parents of homozygous FH 42 of apo(a) phenotype 51/48, in whom there is an apparent dose effect of the LDL receptor gene on $\mathrm{Lp}(\mathrm{a})$ concentration, have an anomalously high $\mathrm{Lp}(\mathrm{a})$ concentration themselves. Although it was not possible to obtain fasting plasma from all the subjects in this study, the data shown in Appendix 1 suggests that some members of the family 


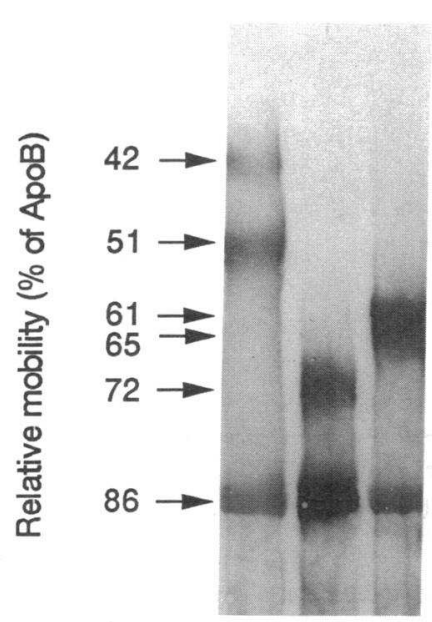

a b c

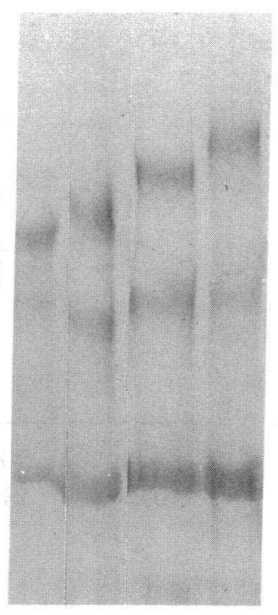

d e f g

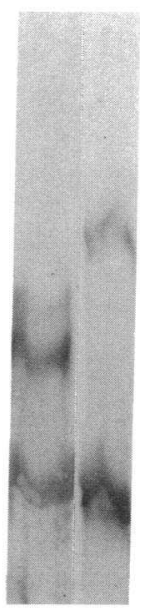

h i

B

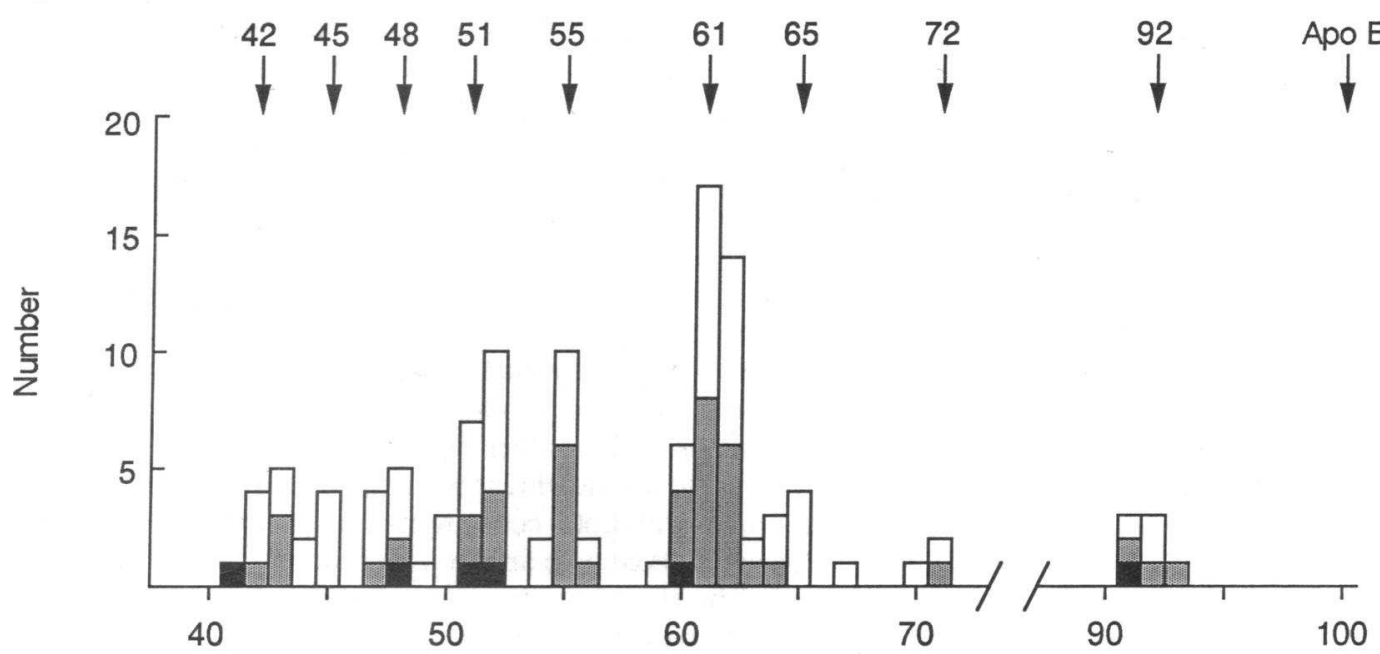

Relative mobility ( $\%$ of ApoB)

Figure 6. Relative mobility of apo B of apo(a) bands detected by immunoblotting. Portions of whole plasma were delipidated and fractionated by SDS-PAGE in 3\% polyacrylamide gels. Proteins were transferred to nitrocellulose and apo(a) detected with specific antibodies as described in Methods. (A) Apo(a) bands from a representative set of samples and three standards (lanes $a$, $b$, and $c$ ) with apo(a) whose mobilities, indicated as a percentage of that of apo B, had previously been determined in 5\% polyacrylamide gels. Lane $d$, sample 27, phenotype $61 / 51$ (equivalent of $2.5 \mu \mathrm{l}$ of plasma applied, containing $\sim 1 \mu \mathrm{g}$ of $\mathrm{Lp}(\mathrm{a})$; lane $e$, sample 52 , phenotype $65 / 48$ (equivalent of $5 \mu \mathrm{l}$, $1.5 \mu \mathrm{g}$ of $\mathrm{Lp}(\mathrm{a})$; lane $f$, sample 71, phenotype 61/ 45 (equivalent of $7.5 \mu \mathrm{l}$, $1.1 \mu \mathrm{g}$ of $\mathrm{Lp}(\mathrm{a})$; lane $g$, sample 36, phenotype 61/ 42 (equivalent of $5 \mu \mathrm{l}, 1$ $\mu \mathrm{g}$ of Lp(a); lane $h$, sample 18 , phenotype $71 / 61$ (equivalent of $15 \mu \mathrm{l}, 3.6$ $\mu \mathrm{g}$ of $\mathrm{Lp}(\mathrm{a})$; lane $i$, sample 15 , phenotype $92 / 51$ (equivalent of $15 \mu \mathrm{l}, 8 \mu \mathrm{g}$ of $\mathrm{Lp}(\mathrm{a})$. Lanes $h$ and $i$ were deliberately overloaded to show the minor bands. The samples in lanes $d-g$ were chosen to illustrate the bands and their pattern of a more prominent higher molec-

ular weight band is not typical of the majority of samples in which the lower molecular weight band predominates, as in lanes $h$ and $i$. The band that runs with a mobility of 90 in each lane is of an unknown protein which is detected by some, but not all preparations of the commercial antibody. $(B)$ The relative mobilities to apo $B$ of the apo(a) bands in each sample were determined by comparison with standards run on the same gel. The figure shows the number of bands of each mobility observed in samples from the 41 normal subjects (open columns), the $22 \mathrm{FH}$ heterozygotes (half-shaded columns), and the 3 homozygotes (fully-shaded columns). The arrows show the mean mobility of each identified apo(a) phenotypic band (see text for details).

may be hypertriglyceridemic. However, of the 14 potentially hypertriglyceridemic subjects, only five had an anomalously high concentration of $\mathrm{Lp}(\mathrm{a})$ in plasma. Of these, two were $\mathrm{FH}$ homozygotes, one was a heterozygote, and two were non-FH.

\section{Discussion}

In this study, the plasma lipid and lipoprotein concentrations have been determined in a large Muslim Asian-Indian kindred of 66 individuals of whom one-third have inherited one normal and one defective allele for the LDL receptor. The defective allele was identified by gene amplification and has been described previously in several members of the kindred (13). Three individuals who are homozygous for the defective LDL receptor allele were also identified, each a child of consanguinous marriage. Without exception, the heterozygous individuals had a raised plasma cholesterol concentration compared with the unaffected relatives, and there was no suggestion of any 


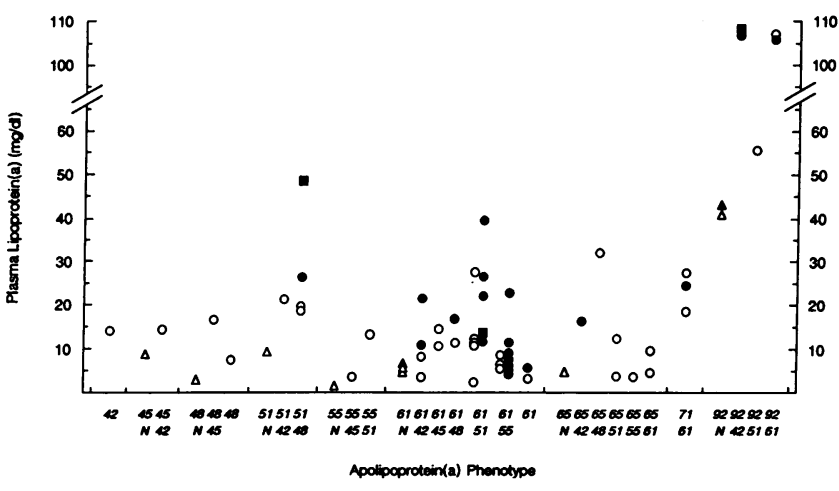

Figure 7. Concentration of $\mathrm{Lp}(\mathrm{a})$ in plasma of individuals in the kindred with different apo(a) phenotypes. Plasma Lp(a) concentration was determined by an ELISA method as described in the Methods. Apo(a) phenotype was assigned on the basis of the relative mobility of apo(a) and apo B after fractionation of whole plasma by SDSPAGE, as described in the legend to Fig. 6. Subjects are grouped according to their apo(a) variant with greater electrophoretic mobility; for the majority, this was the dominant phenotypic apo(a) band. An apparently null phenotype is denoted as $N$. Single numbers denote phenotypes that could be either homozygous for the same phenotypic band or heterozygous for a null phenotype.

suppression of the expression of the defective allele in any of the family members as described recently in a Puerto Rican kindred with familial hypercholesterolemia (21). However, the mean value for LDL cholesterol in the heterozygotes, the large majority of whom were receiving no lipid-lowering therapy, was $343.3 \pm 55 \mathrm{mg} / \mathrm{dl}$ and for the three homozygotes before treatment was $650 \pm 27.2 \mathrm{mg} / \mathrm{dl}$; these values are at the lower end of the reported range for heterogeneous groups of FH heterozygotes and homozygotes (22). Furthermore, although the mean values for HDL cholesterol and plasma apo AI were lower in the FH heterozygotes than in the unaffected individuals, they were not significantly so. These observations may in part explain the remarkable lack of evidence of premature coronary heart disease in the affected individuals in this kindred. Of 22 heterozygotes with one defective LDL receptor allele, only two had symptomatic CHD and each was in the seventh decade of life. None of the heterozygotes identified by genotyping had clearly defined tendon xanthomata, although they were present in all three homozygotes. Thus, although one of the original objectives of this study was to determine whether there was any variation in the severity of CHD symptoms in FH heterozygotes with precisely the same inherited defect in the LDL receptor, this was clearly not possible.

The second objective of this study was to examine the relationship between FH and $\mathrm{Lp}(\mathrm{a})$ concentration, because it has recently been suggested that heterozygous $\mathrm{FH}$ patients have a plasma concentration of $L p(a)$ that is, on average, threefold that of normal individuals with the same apo(a) phenotype (12). We did not observe this phenomenon in the kindred described in this paper, despite the similar genetic background of many of the individuals due to consanguinous marriage. Indeed, in many instances it was possible to identify pairs of siblings of the same apo(a) phenotype, one heterozygous for the defective LDL receptor allele and the other apparently normal, in whom the plasma $\mathrm{Lp}(\mathrm{a})$ concentration was virtually identical.

For the kindred described in this paper, the classification of apo(a) phenotype that has been described previously (9) was not adequate to distinguish between subjects with clearly different phenotypic bands, and thus for this study we have classified apo(a) phenotype simply by measuring the relative electrophoretic mobility of the apo(a) bands. Because the values fell into discreet groups rather than as a continuous spectrum, we are confident that these represent different phenotypic bands. In a recent study, Gaubatz et al. (23) were able to detect one or two separate apo(a) bands in more than $99 \%$ of 692 samples assayed, and identified 11 different phenotypic bands. No significant difference in $\mathrm{Lp}(\mathrm{a})$ concentration between groups of FH and normal with the same apo(a) phenotype was observed, although the mean value for the FH heterozygotes was frequently greater than that of the non-FH individuals. In one family, an FH heterozygote and his FH homozygote daughter, each with apo(a) phenotype $51 / 48$, there appeared to be a possible gene dosage relationship between the defective LDL receptor allele and plasma $\mathrm{Lp}(\mathrm{a})$ concentration. However, an unaf-

Table I. Relationship between Apo(a) Phenotype, Lp(a) Concentration in Plasma, and LDL Receptor Genotype in the Kindred

\begin{tabular}{|c|c|c|c|c|c|c|}
\hline Lp(a) phenotype & LDL receptor genotype & $n$ & Lp(a) & $P^{*}$ & LDL cholesterol & $P^{*}$ \\
\hline & & & \multicolumn{2}{|c|}{ mean $\pm S D \mathrm{mg} / 100 \mathrm{ml}$} & \multicolumn{2}{|c|}{ mean $\pm S D \mathrm{mg} / 100 \mathrm{ml}$} \\
\hline \multirow[t]{2}{*}{$61 / 42$} & Normal & 2 & 5.7 & - & 64.5 & - \\
\hline & FH heterozygotes & 2 & 16.1 & & 199.5 & \\
\hline \multirow[t]{2}{*}{$61 / 48$} & Normal & 1 & 11.1 & - & 92 & - \\
\hline & FH heterozygotes & 1 & 16.9 & & 220 & \\
\hline \multirow[t]{3}{*}{$61 / 51$} & Normal & 5 & $12.9 \pm 9.1$ & $>0.1 \mathrm{NS}$ & $94.8 \pm 25.1$ & $<0.01$ \\
\hline & FH heterozygotes & 4 & $24.9 \pm 11.4$ & & $161 \pm 20.04$ & \\
\hline & FH homozygotes & 1 & 13.2 & & 273 & \\
\hline \multirow[t]{2}{*}{$61 / 55$} & Normal & 3 & $6.7 \pm 1.4$ & $>0.25 \mathrm{NS}$ & $97.6 \pm 26.1$ & $<0.01$ \\
\hline & FH heterozygotes & 7 & $9.3 \pm 6.3$ & & $220.6 \pm 47.2$ & \\
\hline \multirow[t]{2}{*}{$61 /$ another $^{8}$} & Normal & 16 & $9.07 \pm 6.0$ & $>0.1 \mathrm{NS}$ & $88.6 \pm 22.4$ & $<0.001$ \\
\hline & FH heterozygotes & 16 & $13.69 \pm 9.6$ & & $200.1 \pm 41.8$ & \\
\hline
\end{tabular}

\footnotetext{
* The statistical significance of the differences between the means for normal and FH heterozygotes in each group was determined with Student's $t$ test. ${ }^{\ddagger} 1$ mo off all treatment. ${ }^{8}$ Includes all subjects, including those listed above, with one dominant 61 phenotypic band, either together with a minor band or with no detectable second band.
} 

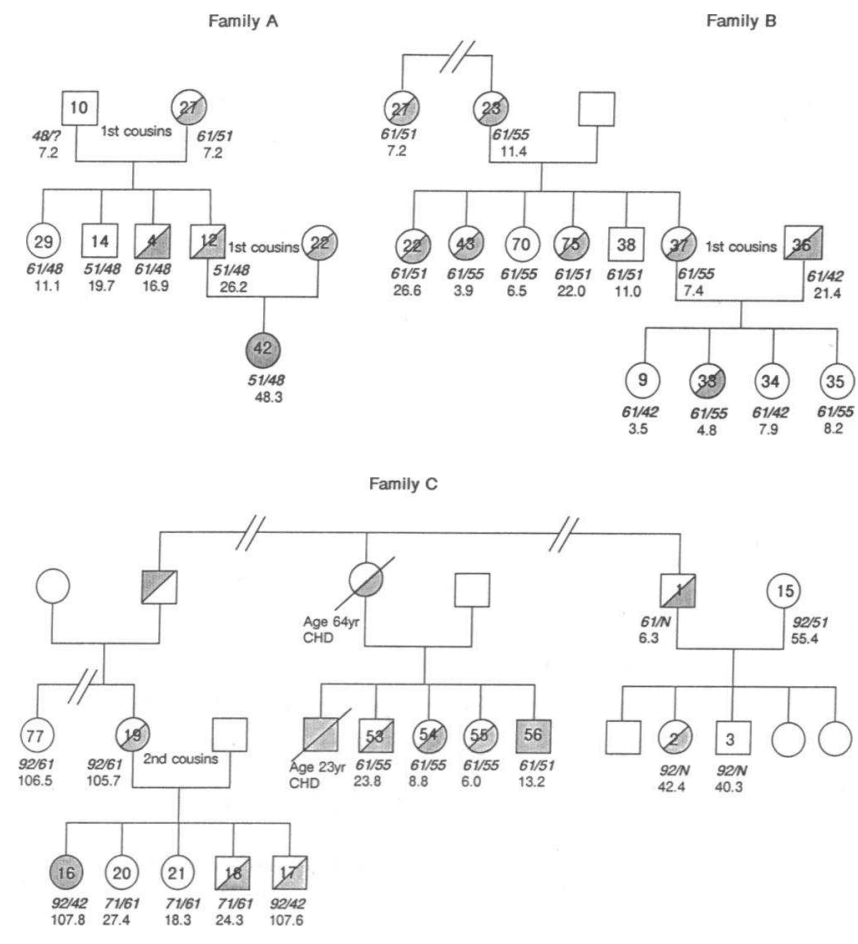

Figure 8. Plasma Lp(a) concentration and apo(a) phenotype in three branches of the family. Plasma apo(a) phenotype and Lp(a) concentration were determined as described in the legends to Figs. 6 and 7. Members of the kindred are identified by numbers within the symbols ( 0 , female; $\square$, male). Half-shaded symbols represent heterozygotes for the pro $_{664} \rightarrow$ leu mutation in the LDL receptor gene; fully-shaded symbols are homozygotes. Deceased individuals are denoted with a diagonal line; the cause of death is shown, where known (CHD, coronary heart disease). The broken lines denote where other siblings have been omitted for clarity.

fected sibling of the father, also with the same apo(a) phenotype, had an Lp(a) concentration very similar to that of his FH heterozygote brother, which reduces the significance of the observed gene dose effect. Furthermore, no such gene dose effect was observed in the immediate families of the other two homozygous FH individuals. Taken together, these data do not provide strong support for the suggestion of Utermann et al. (12) that there is a strong multiplicative interaction between the gene loci for the LDL receptor and apo(a) in determining $L p(a)$ concentration in plasma. Indeed, the effect of such an interaction might be expected to be particularly dominant within this kindred, where other genetic and environmental differences are at a minimum compared with a heterogeneous group of clinically-diagnosed FH heterozygotes. It is of interest that $\mathrm{Ne}$ ven et al. (24) failed to observe an increase in plasma $\mathrm{Lp}(\mathrm{a})$ concentration in individuals with an inherited defect in LDL receptor function compared with unaffected relatives in a family of Rhesus monkeys.

It is not altogether surprising that a simple direct effect of reduced $L D L$ receptor activity on plasma $L p(a)$ concentration was not observed in this kindred, because the question of whether or not $\mathrm{Lp}(\mathrm{a})$ is catabolized via receptor-mediated uptake remains controversial. Armstrong et al. (10) have recently confirmed their earlier observation (25) that $\mathrm{Lp}(\mathrm{a})$ binds to LDL receptors on cultured cells with much lower affinity than LDL and have shown that human $\operatorname{Lp}(a)$ is cleared less well than human LDL by LDL receptor-dependent processes in rat liver. In marked contrast, Hofman et al. (11) found that human $\mathrm{Lp}$ (a) binds with apparent high affinity to isolated LDL receptors, competes equally with LDL for binding to LDL receptors on cultured cells, and is cleared more rapidly from the circulation of transgenic mice expressing high levels of the human LDL receptor gene than from the circulation of normal mice. Although Lp(a) may be catabolized in part by LDL receptordependent means, several lines of independent evidence suggest that this is not an important determinant of $L p(a)$ concentration in human plasma. Firstly, drugs that stimulate LDL receptor activity and reduce plasma LDL do not affect the Lp(a) concentration (26), and secondly, early studies on the turnover of $L p(a)$ in human subjects have suggested that $L p(a)$ concentration in plasma correlates strongly with its production rate but not with its fractional catabolic rate (27). In a recent study, we also observed no difference in the fractional catabolic rate for $L p(a)$ between a group of normal and $\mathrm{FH}$ heterozygotes with matched apo(a) phenotype (28).

One feature that emerged from the data in this paper was that some individuals in the kindred had an anomalously high $\mathrm{Lp}$ (a) concentration compared with the majority of individuals with that particular apo(a) phenotype, and there was some evidence that this could be an inherited trait. Although the trait was more common in FH individuals than in unaffected relatives, and was observed in all three homozygotes, it did not segregate in the pedigree with either the abnormal LDL receptor allele or with apo(a) phenotype. Because several of the nonblood relative spouses were also identified in this group it is possible that it is a relatively common trait, at least amongst this particular racial group. It would be of interest to carry out a similar study on other large kindreds with or without a defective LDL receptor allele. Because so little is known about the regulation of $L p(a)$ metabolism it is difficult to speculate about the nature of the mechanism operating to increase $L p(a)$ concentration in these individuals. Although apo(a) phenotype has been observed to have a strong influence on $\operatorname{Lp}(a)$ concentration in plasma, in a recent study Boerwinkle et al. (29) observed that it only amounts to $\sim 40 \%$ of the variance in $\mathrm{Lp}(\mathrm{a})$ concentration observed in a large population, suggesting that other genetic and environmental factors are also important. The significant risk of premature CHD associated with an increased concentration of $L p(a)$ in plasma and the resistance of $L p(a)$ concentration to reduction by drug treatment suggests that it is worthwhile to identify these factors.

\section{Appendix 1. Details of subjects.}

Each member of the kindred from whom a blood sample was obtained was assigned an identification number (numbers 5769 were not allocated). ${ }^{a}$ Plasma samples not necessarily from fasted individuals. ${ }^{b} \mathrm{CHD}$ present; patient receiving treatment with HMG-CoA reductase inhibitor, $\beta$-blocker, and vasodilator. ${ }^{\circ}$ In third trimester of pregnancy. ${ }^{d}$ Clinically diagnosed FH homozygote treated by two-weekly plasma exchange $(P E)$. Lipid and lipoprotein parameters determined 2 wk after PE. Values obtained at time of referral (untreated) shown in brackets. ${ }^{\circ}$ Clinically diagnosed FH heterozygote treated with HMGCoA reductase inhibitor. ${ }^{\mathrm{f}} \mathrm{Clinically}$ diagnosed $\mathrm{FH}$ homozygote treated with two-weekly plasma exchange and protocol. Lipid and lipoprotein parameters determined 1 wk after PE. Values 
obtained at time of referral (untreated) shown in brackets. In second trimester of pregnancy. hClinically diagnosed $\mathrm{FH}$ homozygote. Off treatment for 1 mo due to gastric ulcer; previously treated with weekly plasma exchange and an HMG-
CoA reductase inhibitor. Values obtained at time of referral (untreated) shown in brackets. Clearly defined tendon xanthomata were only present in the three clinically diagnosed FH

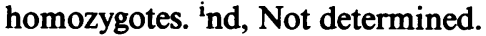

\begin{tabular}{|c|c|c|c|c|c|c|c|c|c|c|c|c|}
\hline Subject & Sex & $\begin{array}{lr}\text { Age } & \text { To } \\
\text { (yr) } & (\end{array}$ & $\begin{array}{l}\text { Total chol. } \\
\text { (mg/dl) }\end{array}$ & $\begin{array}{l}\text { Total } \mathrm{TG}^{\mathrm{a}} \\
(\mathrm{mg} / \mathrm{dl})\end{array}$ & $\begin{array}{l}\text { LDL chol. } \\
\text { (mg/dl) }\end{array}$ & $\begin{array}{l}\text { HDL chol. } \\
\text { (mg/dl) }\end{array}$ & $\begin{array}{l}\text { Total apoB } \\
\text { (mg/dl) }\end{array}$ & $\begin{array}{l}\text { Total apoAI } \\
\text { (mg/dl) }\end{array}$ & $\begin{array}{l}\text { Total Lp(a) } \\
\text { (mg/dl) }\end{array}$ & $\begin{array}{l}\text { Apo(a) } \\
\text { pheno. }\end{array}$ & $\begin{array}{l}\text { ApoE } \\
\text { pheno. }\end{array}$ & $\begin{array}{r}\text { LDL-R } \\
\text { mutatio }\end{array}$ \\
\hline $\begin{array}{l}1 \\
2 \\
3 \\
4 \\
5 \\
6 \\
7 \\
8 \\
9\end{array}$ & $\begin{array}{l}M^{\mathbf{b}} \\
M \\
F \\
M \\
F \\
F \\
F^{\mathbf{c}} \\
M \\
M\end{array}$ & $\begin{array}{r}55 \\
24 \\
18 \\
33 \\
6 \\
7 \\
30 \\
2 \\
20\end{array}$ & $\begin{array}{l}431 \\
290 \\
196 \\
383 \\
158 \\
193 \\
305 \\
312 \\
142\end{array}$ & $\begin{array}{r}380 \\
132 \\
147 \\
193 \\
252 \\
134 \\
212 \\
72 \\
86\end{array}$ & $\begin{array}{r}223 \\
177 \\
84 \\
220 \\
97 \\
65 \\
186 \\
177 \\
59\end{array}$ & $\begin{array}{l}31 \\
31 \\
52 \\
57 \\
81 \\
69 \\
93 \\
55 \\
41\end{array}$ & $\begin{array}{r}198 \\
126 \\
77 \\
155 \\
82 \\
62 \\
128 \\
120 \\
60\end{array}$ & $\begin{array}{r}93 \\
89 \\
118 \\
138 \\
178 \\
172 \\
258 \\
132 \\
96\end{array}$ & $\begin{array}{r}6.3 \\
42.4 \\
40.3 \\
16.9 \\
2.6 \\
5.4 \\
8.4 \\
10.8 \\
3.5\end{array}$ & $\begin{array}{l}61 / \mathrm{N} \\
92 / \mathrm{N} \\
92 / \mathrm{N} \\
61 / 48 \\
48 / \mathrm{N} \\
61 / \mathrm{N} \\
45 / \mathrm{N} \\
61 / 42 \\
61 / 42\end{array}$ & $\begin{array}{l}3 / 4 \\
3 / 3 \\
3 / 3 \\
3 / 3 \\
3 / 3 \\
3 / 3 \\
3 / 3 \\
3 / 3 \\
3 / 3\end{array}$ & $\begin{array}{l}+- \\
+- \\
-- \\
+- \\
-- \\
-- \\
-- \\
+- \\
--\end{array}$ \\
\hline $\begin{array}{l}10 \\
11 \\
12 \\
13 \\
14 \\
15 \\
16 \\
17 \\
18 \\
19\end{array}$ & $\begin{array}{l}M \\
M \\
M \\
M \\
M \\
F \\
F^{\mathbf{d}} \\
M \\
M \\
F\end{array}$ & $\begin{array}{l}60 \\
50 \\
38 \\
31 \\
29 \\
44 \\
14(12) \\
10 \\
12 \\
36\end{array}$ & $\begin{array}{l}227 \\
204 \\
373 \\
194 \\
242 \\
215 \\
545(624) \\
411 \\
325 \\
345\end{array}$ & $\begin{array}{r}150 \\
272 \\
188 \\
306 \\
84 \\
112 \\
258(96) \\
78 \\
76 \\
166\end{array}$ & 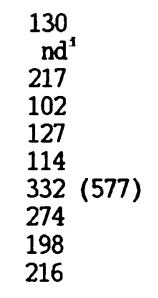 & $\begin{array}{l}40 \\
\text { nd } \\
35 \\
33 \\
48 \\
35 \\
14(26) \\
40 \\
36 \\
29\end{array}$ & $\begin{array}{r}112 \\
\text { nd } \\
174 \\
101 \\
113 \\
102 \\
292 \\
166 \\
137 \\
149\end{array}$ & $\begin{array}{r}104 \\
103 \\
95 \\
100 \\
114 \\
114 \\
41 \\
103 \\
105 \\
94\end{array}$ & $\begin{array}{r}7.2 \\
5.3 \\
26.2 \\
4.5 \\
19.7 \\
55.4 \\
120.5(107.8) \\
107.6 \\
24.3 \\
105.7\end{array}$ & $\begin{array}{l}48 \\
61 / 55 \\
51 / 48 \\
61 / \mathrm{N} \\
51 / 48 \\
92 / 51 \\
92 / 42 \\
92 / 42 \\
71 / 61 \\
92 / 61\end{array}$ & $\begin{array}{l}3 / 4 \\
3 / 4 \\
3 / 3 \\
3 / 3 \\
3 / 3 \\
3 / 3 \\
3 / 3 \\
3 / 3 \\
3 / 3 \\
3 / 3\end{array}$ & $\begin{array}{l}-- \\
-- \\
+- \\
-- \\
-- \\
-- \\
++ \\
+- \\
+- \\
+-\end{array}$ \\
\hline $\begin{array}{l}20 \\
21 \\
22 \\
23 \\
24 \\
25 \\
26 \\
27 \\
28 \\
29\end{array}$ & $\begin{array}{l}F \\
F \\
F \\
F^{b} \\
M \\
F \\
F \\
F^{\mathbf{e}} \\
M \\
F\end{array}$ & $\begin{array}{r}17 \\
13 \\
36 \\
62 \\
13 \\
6 \\
6 \\
64 \\
6 \\
27\end{array}$ & $\begin{array}{l}175 \\
149 \\
292 \\
306 \\
189 \\
139 \\
219 \\
246 \\
160 \\
209\end{array}$ & $\begin{array}{r}82 \\
98 \\
97 \\
143 \\
156 \\
365 \\
115 \\
131 \\
56 \\
67\end{array}$ & $\begin{array}{r}82 \\
76 \\
183 \\
175 \\
91 \\
61 \\
119 \\
135 \\
62 \\
92\end{array}$ & $\begin{array}{l}43 \\
39 \\
33 \\
41 \\
44 \\
29 \\
39 \\
42 \\
60 \\
63\end{array}$ & $\begin{array}{r}76 \\
69 \\
158 \\
142 \\
91 \\
71 \\
106 \\
119 \\
67 \\
87\end{array}$ & $\begin{array}{r}110 \\
101 \\
131 \\
118 \\
110 \\
94 \\
112 \\
131 \\
89 \\
158\end{array}$ & $\begin{array}{r}27.4 \\
18.3 \\
26.6 \\
11.4 \\
4.3 \\
3.6 \\
21.1 \\
39.3 \\
3.0 \\
11.1\end{array}$ & $\begin{array}{l}71 / 61 \\
71 / 61 \\
61 / 51 \\
61 / 55 \\
65 / 61 \\
65 / 51 \\
51 / 42 \\
61 / 51 \\
61 \\
61 / 48\end{array}$ & $\begin{array}{l}3 / 3 \\
3 / 3 \\
3 / 3 \\
3 / 3 \\
3 / 3 \\
3 / 3 \\
3 / 3 \\
3 / 3 \\
2 / 3 \\
3 / 4\end{array}$ & $\begin{array}{l}-- \\
-- \\
+- \\
+- \\
-- \\
-- \\
-- \\
+- \\
-- \\
--\end{array}$ \\
\hline $\begin{array}{l}30 \\
31 \\
32 \\
33 \\
34 \\
35 \\
36 \\
37 \\
38 \\
39\end{array}$ & $\begin{array}{l}\mathbf{F} \\
\mathbf{F} \\
\mathbf{F} \\
\mathbf{F} \\
\mathbf{M} \\
\mathbf{F} \\
\mathbf{M} \\
\mathrm{F} \\
\mathbf{M} \\
\mathbf{M}\end{array}$ & $\begin{array}{r}27 \\
5 \\
6 \\
14 \\
12 \\
10 \\
45 \\
40 \\
4 \\
37\end{array}$ & $\begin{array}{l}155 \\
157 \\
187 \\
292 \\
159 \\
157 \\
360 \\
361 \\
184 \\
225\end{array}$ & $\begin{array}{r}145 \\
114 \\
152 \\
68 \\
74 \\
140 \\
128 \\
137 \\
287 \\
263\end{array}$ & $\begin{array}{r}72 \\
69 \\
80 \\
172 \\
70 \\
69 \\
222 \\
218 \\
86 \\
129\end{array}$ & $\begin{array}{l}35 \\
33 \\
50 \\
35 \\
38 \\
38 \\
26 \\
34 \\
35 \\
24\end{array}$ & $\begin{array}{r}80 \\
79 \\
88 \\
131 \\
82 \\
81 \\
180 \\
191 \\
99 \\
146\end{array}$ & $\begin{array}{r}109 \\
122 \\
147 \\
91 \\
112 \\
116 \\
89 \\
131 \\
122 \\
96\end{array}$ & $\begin{array}{r}14.2 \\
4.4 \\
9.5 \\
4.8 \\
7.9 \\
8.2 \\
21.4 \\
7.4 \\
11.0 \\
11.3\end{array}$ & $\begin{array}{l}45 / 42 \\
65 / \mathrm{N} \\
65 / 61 \\
61 / 55 \\
61 / 42 \\
61 / 55 \\
61 / 42 \\
61 / 55 \\
61 / 51 \\
61 / 51\end{array}$ & $\begin{array}{l}3 / 4 \\
3 / 3 \\
3 / 3 \\
3 / 3 \\
3 / 3 \\
3 / 3 \\
3 / 3 \\
3 / 3 \\
3 / 3 \\
3 / 3\end{array}$ & $\begin{array}{l}- \\
-- \\
-- \\
+- \\
-- \\
-- \\
+- \\
+- \\
-- \\
--\end{array}$ \\
\hline $\begin{array}{l}40 \\
41 \\
42 \\
43 \\
44 \\
45 \\
46 \\
47 \\
48 \\
49\end{array}$ & $\begin{array}{l}F \\
F \\
F^{\mathbf{C}} \\
F^{\mathbf{g}} \\
M \\
F \\
M \\
F \\
F \\
F\end{array}$ & $\begin{array}{r}30 \\
45 \\
16 \\
33 \\
23 \\
19 \\
19 \\
25 \\
4 \\
70\end{array}$ & $\begin{array}{l}163 \\
243 \\
339(678) \\
444 \\
202 \\
188 \\
198 \\
172 \\
315 \\
404\end{array}$ & $\begin{array}{l}116 \\
413 \\
125(61) \\
161 \\
179 \\
215 \\
204 \\
52 \\
164 \\
273\end{array}$ & $\begin{array}{r}70 \\
121 \\
220 \quad(634) \\
256 \\
97 \\
85 \\
88 \\
49 \\
233 \\
238\end{array}$ & $\begin{array}{l}44 \\
34 \\
23(31.3) \\
57 \\
34 \\
55 \\
53 \\
65 \\
34 \\
21\end{array}$ & $\begin{array}{r}79 \\
131 \\
203 \\
236 \\
116 \\
118 \\
107 \\
76 \\
169 \\
222\end{array}$ & $\begin{array}{r}124 \\
129 \\
79 \\
180 \\
112 \\
198 \\
124 \\
165 \\
82 \\
86\end{array}$ & $\begin{array}{r}3.6 \\
9.0 \\
29.7(48.3) \\
3.9 \\
13.1 \\
27.7 \\
1.3 \\
12.2 \\
11.6 \\
16.5\end{array}$ & $\begin{array}{l}65 / 55 \\
51 / \mathrm{N} \\
51 / 48 \\
61 / 55 \\
55 / 51 \\
61 / 51 \\
55 / \mathrm{N} \\
65 / 51 \\
61 / 51 \\
65 / 42\end{array}$ & $\begin{array}{l}3 / 3 \\
3 / 3 \\
3 / 3 \\
3 / 3 \\
3 / 4 \\
3 / 4 \\
3 / 3 \\
3 / 3 \\
3 / 3 \\
3 / 4\end{array}$ & $\begin{array}{l}-- \\
-- \\
++ \\
+- \\
-- \\
-- \\
-- \\
-- \\
+- \\
+-\end{array}$ \\
\hline $\begin{array}{l}50 \\
51 \\
52 \\
53 \\
54 \\
55 \\
56\end{array}$ & $\begin{array}{l}\mathbf{F} \\
\mathbf{M} \\
\mathbf{M} \\
\mathbf{M} \\
\mathbf{F} \\
\mathbf{F} \\
\mathbf{M}^{\mathbf{h}}\end{array}$ & $\begin{array}{l}26 \\
43 \\
35 \\
32 \\
37 \\
29 \\
26\end{array}$ & $\begin{array}{l}403 \\
189 \\
208 \\
306 \\
354 \\
252 \\
393(693)\end{array}$ & $\begin{array}{r}148 \\
86 \\
245 \\
83 \\
55 \\
71 \\
383(78)\end{array}$ & $\begin{array}{r}95 \\
168 \\
97 \\
244 \\
296 \\
183 \\
273(643)\end{array}$ & $\begin{array}{l}39 \\
26 \\
63 \\
33 \\
49 \\
46 \\
27(26)\end{array}$ & $\begin{array}{r}92 \\
158 \\
117 \\
138 \\
133 \\
104 \\
185\end{array}$ & $\begin{array}{r}121 \\
119 \\
99 \\
96 \\
107 \\
110 \\
76\end{array}$ & $\begin{array}{r}18.6 \\
5.5 \\
32.0 \\
22.8 \\
8.8 \\
6.0 \\
13.2 \text { (nd) }\end{array}$ & $\begin{array}{l}51 / 48 \\
61 \\
65 / 48 \\
61 / 55 \\
61 / 55 \\
61 / 55 \\
61 / 51\end{array}$ & $\begin{array}{l}3 / 3 \\
3 / 3 \\
3 / 3 \\
3 / 3 \\
3 / 4 \\
3 / 4 \\
3 / 4\end{array}$ & $\begin{array}{l}- \\
+- \\
- \\
+- \\
+- \\
+- \\
++\end{array}$ \\
\hline $\begin{array}{l}70 \\
71 \\
72 \\
73 \\
74 \\
75 \\
76 \\
77 \\
78 \\
79\end{array}$ & $\begin{array}{l}F \\
F \\
F \\
F \\
M \\
F \\
M \\
F \\
F \\
M\end{array}$ & $\begin{array}{r}33 \\
7 \\
11 \\
3 \\
38 \\
30 \\
37 \\
38 \\
18 \\
14\end{array}$ & $\begin{array}{l}185 \\
177 \\
214 \\
187 \\
183 \\
347 \\
191 \\
187 \\
198 \\
146\end{array}$ & $\begin{array}{r}55 \\
57 \\
81 \\
61 \\
105 \\
61 \\
238 \\
90 \\
121 \\
159\end{array}$ & $\begin{array}{r}104 \\
89 \\
112 \\
96 \\
91 \\
162 \\
109 \\
124 \\
110 \\
64\end{array}$ & $\begin{array}{l}51 \\
59 \\
66 \\
55 \\
48 \\
32 \\
33 \\
31 \\
52 \\
49\end{array}$ & $\begin{array}{r}78 \\
60 \\
86 \\
73 \\
75 \\
141 \\
79 \\
89 \\
79 \\
46\end{array}$ & $\begin{array}{r}117 \\
132 \\
148 \\
124 \\
130 \\
130 \\
95 \\
92 \\
142 \\
111\end{array}$ & $\begin{array}{r}6.5 \\
14.5 \\
10.7 \\
3.1 \\
16.6 \\
22.0 \\
14.0 \\
106.0 \\
12.2 \\
2.3\end{array}$ & $\begin{array}{l}61 / 55 \\
61 / 45 \\
61 / 45 \\
55 / 45 \\
48 / 45 \\
61 / 51 \\
42 \\
92 / 61 \\
61 / 51 \\
61 / 51\end{array}$ & $\begin{array}{l}3 / 3 \\
3 / 3 \\
3 / 3 \\
3 / 3 \\
3 / 3 \\
3 / 3 \\
3 / 3 \\
3 / 3 \\
3 / 3 \\
3 / 3\end{array}$ & $\begin{array}{l}- \\
- \\
- \\
- \\
- \\
- \\
+- \\
+- \\
-- \\
-- \\
-- \\
-\end{array}$ \\
\hline
\end{tabular}




\section{Acknowledgments}

The authors are grateful to Dr. G. R. Thompson (Medical Research Council Lipoprotein Team) for access to clinical samples from his patients. Mrs. S. Niththyananthan and Mr. N. Perombelon provided excellent technical assistance, and we are indebted to Mrs. E. Manson for typing the manuscript. We would also like to express our appreciation to the members of the family for their willing cooperation.

Part of the work described in this paper was supported by a grant from the British Heart Foundation (BHF 89/51).

\section{References}

1. Brown, M. S., and J. L. Goldstein. 1986. A receptor-mediated pathway for cholesterol homeostasis. Science (Wash. DC). 232:34-47.

2. Fredrickson, D. S., J. L. Goldstein, and M. S. Brown. 1978. The familial hyperlipoproteinaemias. In The Metabolic Basis of Inherited Disease. 3rd ed. J. B. Stanbury, J. B. Wyngaarden, and D. S. Fredrickson, editors. McGraw-Hill Inc., New York. 604-655.

3. Myant, N. B. 1990. Cholesterol Metabolism, LDL and the LDL-Receptor. Academic Press, Inc., San Diego. 362-365.

4. Kannel, W. B., T. R. Dawber, A. Kagan, N. Revotskie, and J. Stokes. 1961. Factors of risk in the development of coronary heart disease-six year follow-up experience. The Framingham Study. Ann. Intern. Med. 55:33-50.

5. Morrisett, J. D., J. R. Guyton, J. W. Gaubatz, and A. M. Gotto, Jr. 1987. Plasma Lipoproteins: New Comprehensive Biochemistry. A. M. Gotto, Jr., editor. Elsevier Science Publishers B.V., Amsterdam. 14:129-152.

6. Seed, M., F. Hoppichler, D. Reaveley, S. McCarthy, G. R. Thompson, E. Boerwinkle, and G. Utermann. 1990. Relation of serum lipoprotein(a) concentration and apolipoprotein(a) phenotype to coronary heart disease in patients with familial hypercholesterolemia. $N$. Engl. J. Med. 322:1494-1499.

7. Gaubatz, J. W., C. Heidemann, A. M. Gotto, Jr., J. D. Morrisett, and G. Dahlen. 1983. Human plasma lipoprotein(a): structural properties. J. Biol. Chem. 258:4582-4589.

8. Fless, G. M., C. A. Rolih, and A. M. Scanu. 1984. Heterogeneity of human plasma lipoprotein(a). J. Biol. Chem. 259:11470-11478.

9. Utermann, G., H. J. Menzel, H. G. Kraft, H. C. Duba, H. G. Kemmler, and C. Seitz. 1987. Lp(a) glycoprotein phenotypes. J. Clin. Invest. 80:458-465.

10. Armstrong, V. W., B. Harrach, H. Robenek, M. Helmhold, A. K. Walli, and D. Seidel. 1990. Heterogeneity of human lipoprotein Lp(a). J. Lipid Res. 31:429-441.

11. Hofman, S. L., D. L. Eaton, M. S. Brown, W. J. McConathy, J. L. Goldstein, and R. E. Hammer. 1990. Over expression of human low density lipoprotein receptors leads to accelerated catabolism of $\mathrm{Lp}(\mathrm{a})$ lipoprotein in transgenic mice. J. Clin. Invest. 85:1542-1547.

12. Utermann, G., F. Hoppichler, H. Dieplinger, M. Seed, G. R. Thompson, and $\mathrm{E}$. Boerwinkle. 1989. Defects in the low density lipoprotein receptor gene affect lipoprotein(a) levels. Proc. Natl. Acad. Sci. USA. 86:4171-4174.

13. Soutar, A. K., B. L. Knight, and D. D. Patel. 1989. Identification of a point mutation in growth factor repeat $\mathrm{C}$ of the low density lipoprotein-receptor gene in a patient with homozygous familial hypercholesterolaemia that affects ligand binding and intracellular movement of receptors. Proc. Natl. Acad. Sci. USA. 86:4166-4170.

14. Knight, B. L., S. J. P. Gavigan, A. K. Soutar, and D. D. Patel. 1989. Defective processing and binding of low density lipoprotein receptors in fibroblasts from a familial hypercholesterolaemic subject. Eur. J. Biochem. 179:693698.

15. Grimberg, J., S. Nawoschik, L. Belluscio, R. McKee, A. Turek, and A. Eisenberg. 1989. A simple and efficient non-organic procedure for the isolation of genomic DNA from blood. Nucl. Acids Res. 17:8390.

16. Burstein, M., and H. R. Schotnick. 1973. Lipoprotein-polyanion-metal interactions. Adv. Lip. Res. 11:67-108.

17. Kraft H.-G., H. Dieplinger, E. Hoye, and G. Utermann. 1988. Lp(a) phenotyping by immunoblotting with polyclonal and monoclonal antibodies. Arteriosclerosis. 8:212-216.

18. Laemmli, U. K. 1970. Cleavage of structural proteins during the assembly of the head of bacteriophage T4. Nature (Lond.). 227:680-685.

19. Beisiegel, U., W. J. Schneider, M. S. Brown, and J. L. Goldstein. 1982. Immunoblot analysis of low density lipoprotein receptors in fibroblasts from subjects with familial hypercholesterolaemia. J. Biol. Chem. 257:13150-13156.

20. Warnick, G. R., C. Mayfield, J. J. Albers, and W. R. Hazzard. 1979. Gel isoelectric focussing method for specific diagnosis of familial hyperlipoproteinaemia Type III. Clin. Chem. 25:279-284.

21. Hobbs, H. H., E. Leitersdorf, C. C. Leffent, D. R. Cryer, M. S. Brown, and J. L. Goldstein. 1989. Evidence for a dominant gene that suppresses hypercholesterolaemia in a family with defective low density lipoprotein receptors. J. Clin. Invest. 84:656-664.

22. Myant, N. B. 1990. Cholesterol Metabolism, LDL and the LDL Receptor. Academic Press, Inc., San Diego. 406.

23. Gaubatz, J. W., K. I. Ghanem, J. Guevara, Jr., M. L. Nava, W. Patsch, and J. D. Morrisett. 1990. Polymorphic forms of apolipoprotein(a) inheritance and relationship of their molecular weights to plasma levels of lipoprotein(a). J. Lipid Res. 31:603-613.

24. Neven, L., A. Khalil, D. Pfaffinge, G. M. Fless, E. Jackson, and A. M. Scanu. 1990. Rhesus monkey model of familial hypercholesterolaemia: relation between plasma Lp(a) levels, apo(a) isoforms and LDL-receptor function. $J$. Lipid Res. 31:633-643.

25. Armstrong, V. W., A. K. Walli, and D. Seidel. 1985. Isolation, characterization and uptake in human fibroblasts of an apo(a)-free lipoprotein obtained on reduction of lipoprotein(a). J. Lipid Res. 26:1314-1323.

26. Thiery, J., V. W. Armstrong, J. Scheef, C. Cventzfeld, W. Creutzfeld, and D. Seidel. 1988. Serum lipoprotein Lp(a) concentrations are not influenced by an HMG CoA reductase inhibitor. Klin. Wochenschr. 66:462-463.

27. Krempler, F., G. M. Kostner, A. Roscher, F. Haslauer, K. Bolzano, and F. Sanhofer. 1983. Studies on the role of specific cell surface receptors in the removal of lipoprotein(a) in man. J. Clin. Invest. 71:1431-1441.

28. Knight, B. L., D. Wade, M. Seed, and A. K. Soutar. 1990. Catabolism of lipoprotein(a) in normal and familial hypercholesterolaemic subjects. 55th Annual Meeting, European Atherosclerosis Society, Brugge. (Abstr. 155).

29. Boerwinkle, E., H. J. Menzel, H. G. Kraft, and G. Utermann. 1989. Genetics of the quantitative $\mathrm{Lp}$ (a) lipoprotein trait (III). Hum. Genet. 82:73-78. 